\title{
PENERAPAN LOGAM ANTIMIKROBA (KAWAT TEMBAGA) UNTUK MENURUNKAN KADAR E-COLI, TOTAL COLIFORM DAN TEMBAGA PADA AIR SUNGAI
}

\author{
Pungut $^{1)}$, Joko Sutrisno ${ }^{1)}$, dan Didik Nuryanto ${ }^{1)}$, \\ ${ }^{1)}$ Program Studi Teknik Lingkungan, Fakultas Teknik Universitas PGRI Adi Buana Surabaya \\ Email: didiknuryanto94@gmail.com
}

\begin{abstract}
Abstrak
Beberapa tahun terakhir kualitas sungai di Indonesia mengalami penurunan, terutama setelah melalui daerah permukiman, industri dan pertanian. Bakteri Escherichia Coli (E.coli) adalah bakteri yang paling banyak mengkontaminasi air. Logam merupakan alternatif desinfeksi yang potensial untuk digunakan. Tembaga adalah antimikroba yang memiliki kemampuan melawan bakteri. Tujuan dari penelitian ini adalah untuk mengetahui removal kadar E.coli, Total coliform dan kadar Tembaga dengan menggunakan kawat tembaga. Air hasil filtrasi direndam di 3 reaktor yang terbuat dari fiber plastik berisi kawat tembaga variasi panjang kawat tembaga 6 meter, 9 meter dan 12 meter dan diambil sampel untuk diuji laboratorium setiap 2,5 jam sebanyak 3 kali. Efisiensi removal yang optimum kadar E.coli , Total Coliform dan kadar Tembaga dengan variasi kawat tembaga 6 meter, 9 meter dan 12 meter dan variasi waktu 2,5 jam, 5 jam dan 7,5 jam adalah kadar e.coli $60 \%$ turun setelah 7,5 jam perendaman kawat tembaga panjang 6 meter. Sedangkan kadar total colifom mencapai optimal pada variasi kawat tembaga panjang 9 meter dengan waktu 5 jam sebanyak $70,92 \%$. Dan kadar tembaga dalam air tidak ada penurunan maupun kenaikan kadar dari semua variasi (konstan). Kawat tembaga mampu menurunkan kadar E.coli dan total Coliform. Sedangkan perbedaan kawat tembaga tidak memiliki pengaruh terhadap kadar tembaga.
\end{abstract}

Kata Kunci: Kawat Tembaga , Air Sungai, E.Coli, Total Coliform, Kadar Tembaga

\section{Abstract}

In recent years, the river quality in Indonesia has been decreased, especially after going through residential, industrial and agricultural areas. Escherichia Coli (E.coli) is the bacteria that most contaminates water. Metal is a potential disinfection alternative for use. Copper is an antimicrobial that has the ability to fight bacteria. The purpose of this study was to determine the removal of E. coli, Total coliform and Copper content by using copper wire. Filtration water is immersed in 3 reactors made of fiber plastic containing copper wire variations in copper wire lengths of 6 meters, 9 meters and 12 meters and is sampled for laboratory testing every 2.5 hours 3 times. The optimum removal efficiency of E. coli levels, Total Coliform and Copper content with variations of copper wire 6 meters, 9 meters and 12 meters and time variations of 2.5 hours, 5 hours and 7.5 hours is $60 \%$ e.coli levels down after 7.5 hours soaking copper wire 6 meters long. While the total colifom content reached optimal on variations of 9 meter long copper wire with a time of 5 hours as much as $70.92 \%$. And the copper content in water does not decrease nor increase the content of all variations (constant). Copper wire can reduce levels of E. coli and total Coliform. While the difference in copper wire has no effect on copper content.

Keywords: Copper Wire, River Water, E.Coli, Total Coliform, Copper Content

\section{PENDAHULUAN}

Air sungai adalah salah satu air permukaan yang banyak digunakan oleh masyarakat. Sungai merupakan tempat akumulasi pembuangan limbah dari berbagai kegiatan manusia sebelum akhirnya dialirkan ke danau atau laut. Kondisi ini akan mengakibatkan semua bahan pencemar yang terlarut dalam bentuk limbah cair dan padat akan masuk ke dalam aliran sungai. Besarnya bahan pencemar yang masuk ke sungai akan berpengaruh terhadap kualitas air sungai.

Berdasarkan Keputusan Menteri Lingkungan Hidup dan Kehutanan RI Nomor 
68 Tahun 2016 Tentang Baku Mutu Domestik, baku mutu air limbah domestik untuk parameter amoniak sebesar $10 \mathrm{mg} / \mathrm{L}$, pH 6-9, BOD $30 \mathrm{mg} / \mathrm{L}$, COD $100 \mathrm{mg} / \mathrm{L}$, TSS $30 \mathrm{mg} / \mathrm{L}$, minyak dan lemak $5 \mathrm{mg} / \mathrm{L}$, total coliform $3000 \mathrm{Jumlah} / 100 \mathrm{ml}$, dan debit 100 L/org/hari. Salah satu permasalahan yang terjadi saat ini adalah tingginya kadar coliform pada air sungai. Kondisi eksisting kualitas air sungai di Jawa Timur menunjukan konsentrasi Total Coliform sebesar 97,2\% dan Coli tinja 88,79 di lokasi pantau melebihi baku mutu kualitas air sungai kelas II berdasarkan hasil pemantauan kualitas air terpadu yang dilakukan oleh BLH Provinsi Jawa Timur, Perum Jasa Tirta, Dinas Pengairan Provinsi Jawa Timur maupun BLH Kabupaten/Kota. (DLH Prov. Jatim, 2017)

Bakteri Escherichia Coli (E.coli) adalah bakteri yang paling banyak mengkontaminasi air dan memiliki resiko yang langsung dapat dirasakan oleh manusia yang mengkonsumsinya. Penyakit yang paling sering ditimbulkan oleh bakteri E.coli adalah diare. (Sunarko, 2012). Oleh karena itu pengolahan air bersih untuk mendesinfeksi bakteri E.coli dan Total coliform yang murah dan mudah untuk dilakukan dan efisien bagi masyarakat sangat dibutuhkan.

Cara yang paling sering dilakukan untuk mendesinfeksi bakteri adalah dengan metode klorinasi. Penggunaan klorin dalam desinfeksi E.coli memiliki beberapa kekurangan yaitu senyawa klorin yang bersifat karsinogenik dan dapat mempengaruhi rasa dari air bersih yang didesinfeksi. Walaupun dengan klorin membutuhkan biaya yang murah dan mudah dilakukan, namun membutuhkan tingkat pengontrolan dosis penggunaaan yang sangat teliti, dengan kata lain membutuhkan biaya perawatan tinggi. Selain itu klor berpotensi menghasilkan Trihalometan (THMs) akibat adanya reaksi senyawa-senyawa yang bersifat karsinogenik dan mutagenik (L.Mezule et.al, 2009)

Berdasarkan penelitian Varkey (2011) tembaga sebagai desinfektan, dalam bentuk kawat tembaga yang memiliki diameter 0,65 $\mathrm{mm}$ dan berat $10 \mathrm{~g}$ mampu menghilangkan golongan bakteri koliform sebesar 99,99\% dengan merendamnya selama 5 jam. Pada penelitian lain batuan andesit sebagai saringan gerabah dengan ketebalan $2 \mathrm{~cm}$ dan dilengkapi kawat tembaga diameter $0,65 \mathrm{~mm}$ panjang $2 \mathrm{~m}$ mampu menurunkan MPN Coliform sebesar 96,20\%. (Nuryanto,2015) Proses desinfeksi dengan logam merupakan alternatif desinfeksi yang potensial untuk digunakan. Perak merupakan suatu logam yang terbukti efektif sebagai antimikroba, namun penggunaan perak pada masyarakat, sulit untuk dilakukan karena jumlah yang terbatas dan tidak terjangkau oleh masyarakat. Selain perak, ternyata tembaga merupakan logam yang dapat dijadikan sebagai desinfektan (Sutrisno, 2006).

Tembaga sebagai antimikroba yang baik memiliki mekanisme dalam menghadapi bakteri. Dengan adanya interaksi antara membran luar bakteri dengan permukaan tembaga akan menjadikan membran bakteri akan pecah dan hancur setelah adanya interaksi antara keduanya. (Thevasanthi ,2011) Pada penelitian lain menyebutkan mikroba membutuhkan enzim yang mengandung tembaga untuk mendorong reaksi kimia vital tertentu. Namun, kelebihan tembaga dapat memengaruhi protein dan enzim dalam mikroba, sehingga menghambat aktivitasnya. Para peneliti menyatakan bahwa kelebihan tembaga pada sel bakteri berpotensi mengganggu fungsi sel baik di dalam sel maupun di ruang interstitial antar sel. (Biohealth partnership, 2007)

Dalam penelitian ini air sungai akan diolah dengan menggunakan reactor pasir lambat dan reactor kawat tembaga. Hasil survey pendahuluan pada air sungai untuk parameter E.coli sebesar $200 \mathrm{CFU} / 100 \mathrm{ml}$ dan Total Coliform $4800 \mathrm{CFU} / 100 \mathrm{ml}$. Penelitian ini dilakukan dengan menerapkan variasi perbedaan panjang kawat tembaga yaitu panjang 6 meter, 9 meter dan 12 meter dan waktu tinggal 7.5 jam untuk menyisihkan kadar E.coli dan Total Coliform pada air sungai.

Tujuan dari penelitian yaitu mengkaji efisiensi removal kadar E.coli dan Total Coliform berdasarkan variasi perbedaan panjang kawat. Serta untuk mengetahui pengaruh kadar Tembaga setelah dilakukan perendaman selama 7,5 jam. Manfaat dari penelitian ini yaitu dapat dijadikan tambahan pengetahuan cara pengolahan air sungai bagi rumah tangga dengan menggunakan media kawat tembaga dalam menurunkan kadar kadar E.coli dan Total Coliform. 


\section{Peralatan dan Bahan Penelitian}

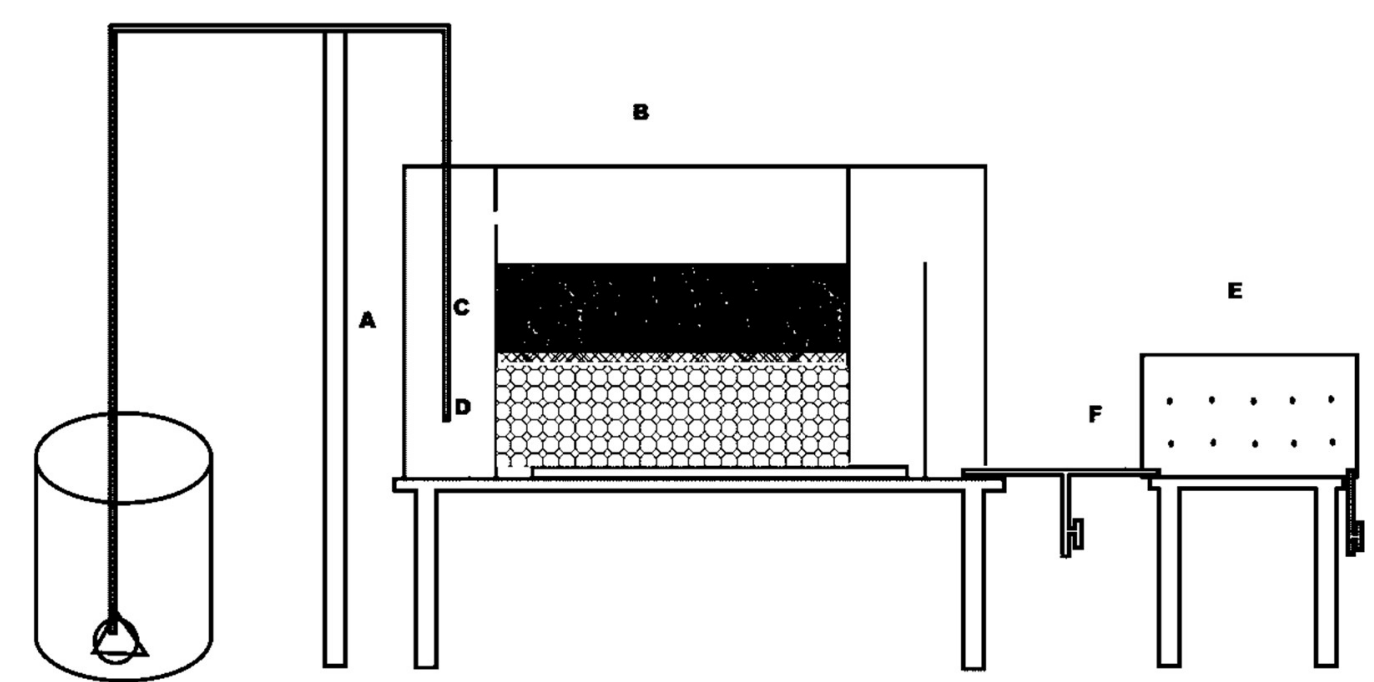

Dalam penelitian ini alat dan bahan yang digunakan berupa air sungai sebanyak 50 liter , pasir dan kerikil sebagai media filtrasi pretreatment dan kawat tembaga. Bak filtrasi menggunakan bahan fiberplastik dengan ketebalan $1 \mathrm{~cm}$ dimensi panjang $70 \mathrm{~cm}$, lebar $30 \mathrm{~cm}$ dan tinggi $50 \mathrm{~cm}$. Media filter berupa pasir dengan diameter butiran $0,6-2 \mathrm{~mm}$ ketebalan $15 \mathrm{~cm}$ dan kerikil dengan diameter 5-12 $\mathrm{mm}$ ketebalan $15 \mathrm{~cm}$ dan dilapisi ijuk di atas media kerikil. Reaktor yang berisi kawat tembaga menggunakan bahan fiberplastik dengan ketebalan $1 \mathrm{~cm}$ dimensi panjang 30 $\mathrm{cm}$, lebar $30 \mathrm{~cm}$ dan tinggi $22 \mathrm{~cm}$ dengan Volume sebesar $18 \mathrm{~L}$. Panjang kawat dengan variasi 6 meter, 9 meter dan 12 meter dengan diameter kawat tembaga dengan ukuran 0,65 $\mathrm{mm}$. Reaktor alat secara lengkap tersaji pada Gambar 1. berikut :

Gambar 1. Design alat tampak samping

Proses awal penelitian ini dengan membersihkan media filter dan rangkaian reaktor menggunakan air bersih. Pencucian media filter pasir yang sudah pernah digunakan, dilakukan dengan mengambil lapisan bagian atas media pasir kemudian dikeruk, dikeluarkan dan dibuang dari bak filter dan diganti dengan yang media yang baru. Media pasir harus segera dicuci untuk mencegah terjadinya kondisi anaerobik pada tumpukan pasir yang dapat menimbulkan rasa atau bau (Hadi, 2012).

Tahap Pengumpulan Data

Pengumpulan data dilakukan dengan menggunakan metode observasi antara lain:

a. Analisis kualitas air sungai sebelum perlakuan meliputi parameter E.coli, Total Coliform dan Kadar $\mathrm{Cu}$

b. Prosedur penelitian adalah sebagai berikut:

- Mengambil sampel setelah proses filtrasi pasir dan kerikil .

- Kemudian air direndam dengan kawat tembaga selama 7,5 jam dengan di sampling tiap 2,5 jam untuk diuji laboratorium parameter E.coli, total coliform dan kadar tembaga. 
c. Proses analisis dilakukan di Laboratorium.

\section{Metode Analisis Data}

Analisa dilakukan dengan mempersentasekan hasil removal kadar E.coli dan total coliform sebelum dan sesudah perlakuan dengan variasi panjang kawat tembaga serta dilakukan analisa terhadap kadar Tembaga yang terlarut dalam air. Data ditampilkan dalam bentuk tabulasi tabel dan grafik untuk melihat removal kadar E.coli dan total Coliform serta kadar Tembaga setelah perlakuan. Uji kadar E.coli dan Total Coliform pada air diukur dengan menggunakan metode sesuai dengan SNI 012332.1-2006 sedangkan Kadar $\mathrm{Cu}$ diukur dengan menggunakan metode SNI 06-6989 62004.

\section{HASIL DAN PEMBAHASAN}

Penelitian ini dilakukan di Jalan Pucang Jajar Timur Kecamatan Mulyorejo Kota Surabaya dengan mengambil air sungai dari Sungai Jagir Wonokromo Sebelum Pintu Air.
Air sungai dialirkan ke sebuah reaktor untuk di filter dengan media pasir dan kerikil kemudian dialirkan ke rekator yang berisi kawat tembaga untuk direndam selama 7,5 jam diambil sampel uji laboratorium setiap 2,5 jam.

Data hasil pengujian E.coli, total coliform dan kadar tembaga variasi panjang kawat tembaga. Hasil pengujian analisis E.coli, total coliform air rendaman kawat tembaga menunjukkan adanya removal masing-masing kadar, namun hasil uji tidak signifikan dan belum sesuai dengan persyaratan PERMENKES No. 32 Tahun 2017 Tentang Persyaratan Air Bersih untuk Keperluan Hiegiene Sanitasi. Namun kadar Tembaga dari sampel awal sebelum perlakuan dan setelah perlakuan tidak ada perubahan kadar yang terjadi.

\section{Karakteristik Awal Air Sungai Sebelum Perlakuan}

Hasil uji karakteristik air sungai sebelum dilakukan pengolahan dapat dilihat pada Tabel 1.

\begin{tabular}{ccc} 
Tabel 1 & \multicolumn{3}{c}{ Hasil Uji Karakteristik Air Sungai Sebelum Perlakuan } \\
\hline \multicolumn{1}{c}{ Parameter } & Satuan & Hasil Uji \\
\hline E.coli & CFU/100ml & 200 \\
Total Coliform & CFU/100ml & 4800 \\
Kadar Tembaga & $\mathrm{mg} / \mathrm{L}$ & $<0,011$ \\
\hline
\end{tabular}

Sumber: Hasil Analisis Laboratorium, 2020

Kualitas air sungai dipengaruhi oleh kualitas pasokan air yang berasal dari daerah tangkapan sedangkan kualitas pasokan air dari daerah tangkapan berkaitan dengan aktivitas manusia yang ada di dalamnya. Perubahan kondisi kualitas air pada aliran sungai merupakan dampak dari buangan dari penggunaan lahan yang ada. Perubahan pola pemanfaatan lahan menjadi lahan pertanian, tegalan dan permukiman serta meningkatnya aktivitas industri akan memberikan dampak terhadap kondisi hidrologis dalam suatu Daerah Aliran Sungai. Selain itu, berbagai aktivitas manusia dalam memenuhi kebutuhan hidupnya yang berasal dari kegiatan industri, rumah tangga, dan pertanian akan menghasilkan limbah yang memberi sumbangan pada penurunan kualitas air sungai (Agustiningsih dkk, 2012). Dari hasil analisis awal sebelum pengolahan di laboratorium diperoleh kadar E-coli sebesar $200 \mathrm{CFU} / 100 \mathrm{ml}$, total coliform sebesar 4800 CFU/100 ml dan kadar tembaga $<0,011$ $\mathrm{mg} / \mathrm{L}$.

\section{Pengaruh Media Filtrasi terhadap Kadar E.coli, Total Coliform dan Kadar Tembaga}

Pengaruh media filtrasi terhadap kadar e.coli, total coliform dan kadar tembaga disajikan pada tabel 2 berikut. Dalam penelitian sebelumnya bahwa proses terlarutnya senyawa tembaga dalam air dipengaruhi oleh beberapa faktor yaitu derajat keasaman, reaksi kimia, temperatur dan waktu. Sedangkan pada saat pengukuran nilai pH menunjukkan nilai 7 , tidak ada penambahan bahan kimia, tidak ada 
perubahan suhu dan tidak terjadi kontak senyawa tembaga.

Tabel 2. Kadar E.coli, Total Coliform dan Kadar Tembaga

\begin{tabular}{lcccc}
\hline \multirow{2}{*}{ Parameter } & \multirow{2}{*}{ Satuan } & \multicolumn{2}{c}{ Hasil Uji } & Persentase \\
\cline { 3 - 4 } & & Sebelum & Sesudah & kenaikan \\
\hline E.coli & CFU/100ml & 200 & 500 & 150 \\
Total Coliform & CFU/100ml & 4800 & 14100 & 193,75 \\
Kadar Tembaga & $\mathrm{mg} / \mathrm{L}$ & $<0,011$ & $<0,011$ & 0 \\
\hline
\end{tabular}

Sumber: Hasil Analisis Laboratorium, 2020

Hasil pengukuran untuk semua parameter uji seperti kadar E.coli, dan total coliform mengalami kenaikan, hal dapat disebabkan oleh beberapa faktor. Pada kadar E-coli hasil uji setelah pengolahan meningkat dari $200 \mathrm{CFU} / 100 \mathrm{ml}$ menjadi $500 \mathrm{CFU} / 100$ ml. sedangkan pada kadar total coliform meningkat dari $4800 \mathrm{CFU} / 100 \mathrm{ml}$ menjadi $14100 \mathrm{CFU} / 100 \mathrm{ml}$. peningkatan parameter uji ini dipengaruhi oleh beberpa faktor seperti pencucian media pasir yang tidak benar merupakan faktor utama terjadinya kenaikan kadar E.coli dan Total Coliform. Kelemahan lain dalam saringan pasir lambat yaitu: apabila algae terdapat dalam jumlah yang melimpah akan menyebabkan pengerukan lapisan atas menjadi terlalu sering. Kondisi air sungai yang menjadi sumber air baku sendiri bersifat komplek, dinamis dan probabilistik karena unsur-unsur di dalamnya mengalami gejala transpor dan transformasi. Air yang masuk ke dalam sungai juga bervariasi terhadap waktu baik pada segi kualitas maupun kuantitasnya (Maharani et al., 2008). Ketika kondisi input dan lingkungan berubah maka komposisi biofilm pun ikut berubah sehingga organisme baru datang bergantian dalam mendominasi (Joubert dan Pillay, 2008).

\section{Pengaruh Kawat Tembaga Terhadap Kadar E.coli}

Tembaga sebagai antimikroba yang baik memiliki mekanisme dalam menghadapi bakteri. Dengan adanya interaksi antara membran luar bakteri dengan permukaan tembaga akan menjadikan membran bakteri akan pecah dan hancur setelah adanya interaksi antara keduanya. (Thevasanthi ,2011) Pada penelitian lain menyebutkan mikroba membutuhkan enzim yang mengandung tembaga untuk mendorong reaksi kimia vital tertentu. Namun, kelebihan tembaga dapat memengaruhi protein dan enzim dalam mikroba, sehingga menghambat aktivitasnya. Para peneliti menyatakan bahwa kelebihan tembaga pada sel bakteri berpotensi mengganggu fungsi sel, baik di dalam sel maupun di ruang interstitial antar sel. (Biohealth partnership, 2007). Berikut analisis removal kadar E.coli dengan variasi panjang kawat dapat dilihat pada gambar 2 berikut:

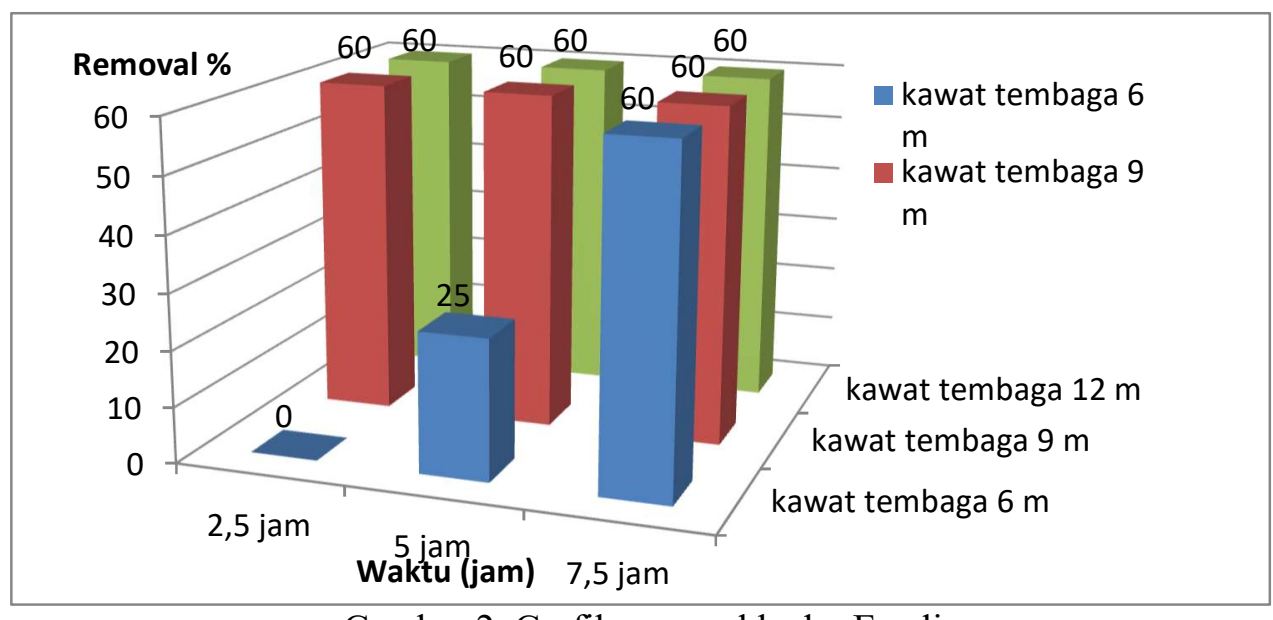

Gambar 2. Grafik removal kadar E.coli 
Pada variasi kawat tembaga panjang 9 meter dan 12 meter kadar E.coli mengalami penurunan pada waktu 2,5 jam kemudian pada waktu berikut tetap tidak ada perubahan. Hal ini dapat disebabkan tidak efektifnya panjang kawat tembaga yang digunakan karena sebelumnya seperti yang telah diungkapkan Varkey 2011 dengan kawat tembaga 10 gram, panjang 2 meter sudah mampu menurunkan 99,25\% bakteri coliform. Sedangkan pada kawat tembaga pajang 6 meter penurunan e.coli terjadi setelah paparan 5 jam. Hal ini sesuai dengan penelitisn Varkey, 2011 bahwa bakteri coliform akan turun setelah paparan 5 jam dengan kawat tembaga.

\section{Pengaruh Kawat Tembaga Terhadap Kadar Total Coliform \\ Istilah fecal Coliform (Koliform tinja)}

menunjukkan bakteri kolifom dari tinja manusia atau hewan berdarah panas lainnya.Koliform merupakan suatu grup bakteri yang digunakan sebagai indikator adanya polusi kotoran dan kondisi sanitasi yang tidak baik terhadap air. Nanopartikel telah memberikan banyak kemajuan siginifikan dalam aplikasi di bidang biomedis. Beberapa jenis nanopartikel yang sering digunakan sebagai antimikroba adalah Emas $(\mathrm{Au})$, Perak $(\mathrm{Ag})$ dan Tembaga $(\mathrm{Cu})$. (Kulkarni et al, 2013). Dalam aplikasi lain kawat tembaga yang memiliki diameter 0,65 $\mathrm{mm}$ dan berat $10 \mathrm{~g}$ mampu menghilangkan golongan bakteri koliform sebesar 99,99\% dengan merendamnya selama 5 jam. (Varkey, 2011). Berikut analisis removal kadar Total Coliform dengan variasi panjang kawat dapat dilihat pada gambar 3 berikut:

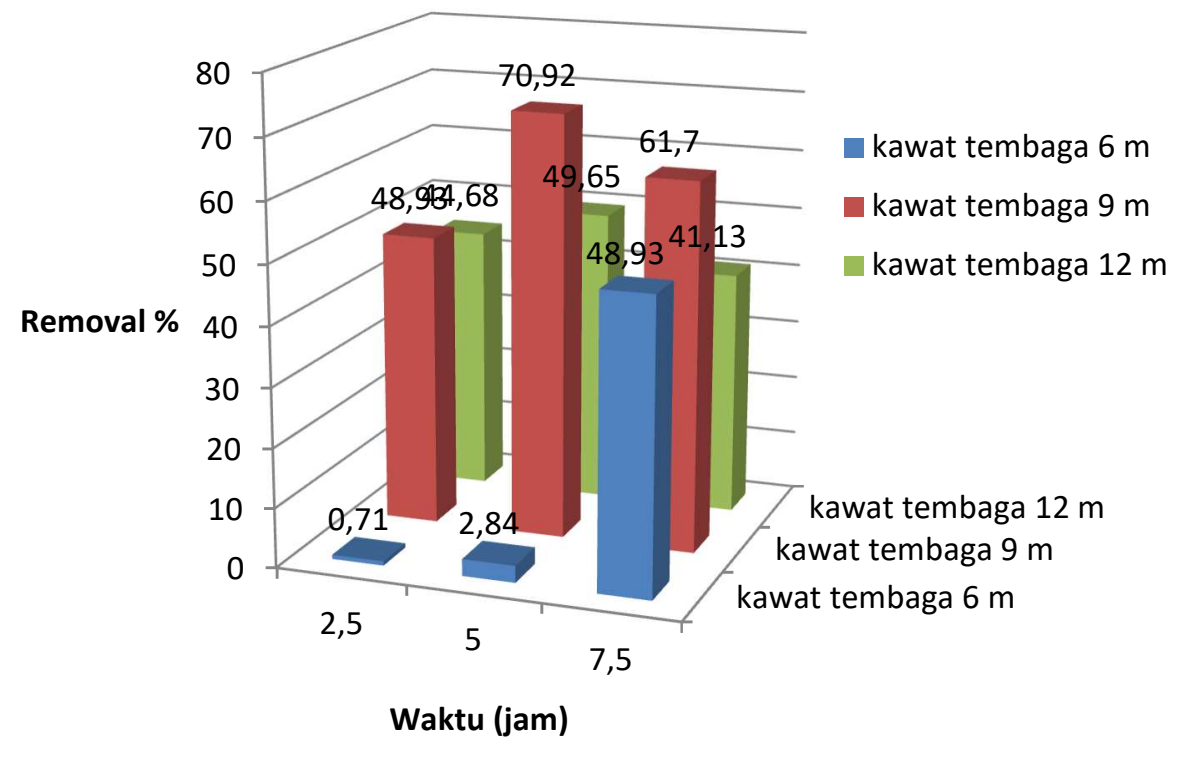

Gambar 3. Grafik Removal Kadar Total Coliform

Hasil removal kadar Total Coliform yang tertinggi terdapat pada variasi kawat tembaga panjang 9 meter dengan waktu 5 jam setelah perendaman yaitu sebesar $70,92 \%$. Namun pada kawat tembaga panjang 9 meter pada waktu 7,5 jam perendaman tingkat efisiensi removal turun menjadi $61,7 \%$. Dapat dilihat pada kawat tembaga 6 meter bahwa efisiensi penurunan kadar Total Coliform menunjukkan grafik yang semakin meningkat seiring berjalannya waktu. Nuryanto (2015) membuktikan dengan kawat tembaga 2 meter seberat $10 \mathrm{~g}$ sudah mampu menghilangkan $99,25 \%$ bakteri coliform.

\section{Pengaruh Kawat Tembaga terhadap Kadar Tembaga}

Logam berat $\mathrm{Cu}$ digolongkan ke dalam logam berat dipentingkan atau logam berat 
essensial: artinya, meskipun $\mathrm{Cu}$ merupakan logam berat beracun, unsur logam ini sangat di butuhkan tubuh meski dalam jumlah yang sedikit. Karena itu, $\mathrm{Cu}$ juga termasuk ke dalam logam - logam essensial bagi manusia, seperti besi $(\mathrm{Fe})$ dan lain - lain. Toksisitas yang dimiliki oleh $\mathrm{Cu}$ baru akan bekerja dan memperlihatkan pengaruhnya bila logam ini telah masuk ke dalam tubuh organisme dalam jumlah besar atau melebihi nilai toleransi organisme terkait. Pengaruh kawat tembaga terhadap kadar tembaga dapat dilihat pada Tabel 4. Berikut :

Tabel 4 . Penurunan Kadar Tembaga

\begin{tabular}{ccccc}
\hline \multirow{2}{*}{ Panjang kawat } & \multicolumn{4}{c}{ Kadar Tembaga $(\mathrm{mg} / \mathrm{L})$} \\
\cline { 2 - 5 } & $\begin{array}{c}\text { Setelah } \\
\text { filtrasi }\end{array}$ & $\begin{array}{c}\text { Setelah } \\
\text { direndam } \\
2,5 \text { jam }\end{array}$ & $\begin{array}{c}\text { Setelah } \\
\text { direndam 5 } \\
\text { jam }\end{array}$ & $\begin{array}{c}\text { Setelah } \\
\text { direndam } \\
7,5 \text { jam }\end{array}$ \\
\hline Paparan kawat $6 \mathrm{~m}$ & $<0,011$ & $<0,011$ & $<0,011$ & $<0,011$ \\
Paparan kawat 9 $\mathrm{m}$ & $<0,011$ & $<0,011$ & $<0,011$ & $<0,011$ \\
Paparan kawat 12 $\mathrm{m}$ & $<0,011$ & $<0,011$ & $<0,011$ & $<0,011$ \\
\hline
\end{tabular}

Sumber: Hasil Analisis Laboratorium, 2020

Tidak terjadi kenaikkan kadar tembaga dalam air setelah air sampel direndam dengan kawat tembaga. Dalam penelitian sebelumnya bahwa proses terlarutnya senyawa tembaga dalam air dipengaruhi oleh beberapa faktor yaitu derajat keasaman, reaksi kimia, temperatur dan waktu. Sedangkan pada saat pengukuran nilai $\mathrm{pH}$ menunjukkan nilai 7 , tidak ada penambahan bahan kimia, tidak ada perubahan suhu dan terjadi kontak tembaga dengan air hanya selama 7,5 jam

\section{KESIMPULAN}

Dari penelitian ini dapat disimpulkan bahwa:

1. Kawat tembaga memiliki kemampuan meremoval E.coli namun perbedaan panjang kawat tembaga tidak memiliki pengaruh terhadap kadar E.coli

2. Kawat tembaga memiliki kemampuan meremoval Total Coliform namun perbedaan panjang kawat tembaga tidak memiliki pengaruh terhadap kadar Total Coliform

3. Kawat tembaga tidak memiliki pengaruh terhadap kadar tembaga setelah perlakuan

4. Hasil kadar E.coli dan Total Coliform yang paling rendah setelah dilakukan treatment kawat tembaga yaitu 200 CFU/100ml dan $4100 \mathrm{CFU} / 100 \mathrm{ml}$ belum memenuhi baku mutu air bersih Permenkes 32 tahun 2017 tentang Persyaratan Kualitas Air Bersih untuk Keperluan Hiegiene Sanitasi yaitu sebesar 0 CFU E.coli dan 10 CFU Total Coliform.

\section{UCAPAN TERIMAKASIH}

Ucapan terimakasih penulis sampaikan kepada Laboratorium Teknik Lingkungan sebagai tempat penelitian dan analisis data hasil penelitian. Selain itu penulis menyampaikan banyak berterima kasih kepada Siti Munawaroh yang telah banyak membantu dalam proses penelitian.

\section{DAFTAR PUSTAKA}

Agustiningsih, dkk. (2012). Analisis Kualitas Air dan Strategi Pengendalian Pencemaran Air Sungai Blukar Kabupaten Kendal. Jurnal Presipitasi : Media Komunikasi dan Pengembangan Teknik Lingkungan, 9(2), 64-71

Dinas Lingkungan Hidup Provinsi Jawa Timur, (2017). Laporan Indeks Kualitas Pengelolaan Lingkungan Hidup Provinsi Jawa Timur. Surabaya : Pemprov Jawa Timur

Hadi, W. (2012). Perencanaan Bangunan Pengolahan Air Minum,. Surabaya : ITS Press

Joubert, E.D., dan Pillay, B. (2008), "Visualisation of the Microbial Colonisation of a Slow Sand Filter using an Encironmental Scanning Electron Microscope", Journal of Biotechnology, Vol.11 
No.2, hal. 1-7.

Maharani, A. Ciptomulyono U., Santosa B. (2008), Pengembangan Model Optimasi Manajemen Pengelolaan Kualitas Air Kali Surabaya dengan Interval Fuzzy Linier Programming (ILFP). Prosiding Seminar Nasional xviii Manajemen Teknologi VIII Institut Teknologi Sepuluh Nopember. Surabaya.

Menteri Kesehatan RI, (2017). Peraturan Menteri Kesehatan No.32 Tahun 2017 tentang Persyaratan Kualitas Air Bersih untuk Keperluan Hiegine Sanitasi. Jakarta : Kementerian Kesehatan

Menteri Kesehatan RI, (2010). Peraturan Menteri Kesehatan No.492/Menkes/Per/IV/1990 tentang Persyaratan Air Minum. Jakarta : Kementerian Kesehatan.

Mezule, L dkk., (2009). A Simple Technique for Water Desinfection with Hydrodynamic Cavitation : Effect on Survival of Escherichia coli, Desalination 248(1-3), 152159

Nuryanto, D, (2015). Kemampuan Saringan Gerabah Batuan Andesit dalam Meningkatkan Kualitas Air Sungai Secara Parameter Fisika dan Mikrobiologis : Karya Tulis Ilmiah. Surabaya : Jurusan Kesehatan Lingkungan Poltekkes Kemenkes Surabaya.

Sutrisno, T, (2006). Teknologi Penyediaan Air Bersih. Jakarta : Rineka Cipta

Thevasanthi,T, Alagar, M. (2011). Studies of Copper Nanoparticles Effects on Micro-organisms. Annals of Biological Research , 2 (3), $368-373$

Tosepu, ,(2010). Kesehatan Lingkungan. Surabaya : Bintang Surabaya

Yudo dan Said,. (2018).Status Kualitas Air Sungai Ciliwung di Wilayah DKI Jakarta. Jurnal Teknologi Lingkungan, 19(1), 13-22

Varkey, J.A, and Dlamini MD., (2011). Point of Use Water Purification Using Clay Pot Water Filter and Copper Mesh, Water SA, 38(5), 721-726 